\title{
The Impact Of Risk Management And Bank Size On Profitability Of Commercial Banking In Indonesia
}

\author{
Nisrul Irawati \\ Department of Management \\ Faculty of Economics and Business, \\ Universitas Sumatera Utara \\ Medan, Indonesia \\ nisrulirawati@yahoo.com
}

\author{
Azhar Maksum \\ Department of Accountancy \\ Faculty of Economics and Business, \\ Universitas Sumatera Utara \\ Medan, Indonesia \\ azharmaksum16@gmail.com
}

\begin{abstract}
The growth of credit in Indonesian Banking industry tends to be slower in period 2011 until 2016 whereas the credit growth only $7.87 \%$ compare to $10.4 \%$ in 2016 . But based on the important role of the banking sector for economic development, the regulator should manage the risk of the credit in order to create a healthy and strong banking industry. According to Bank Indonesia regulation, one of the banking risks is the liquidity risk which BI stipulated two things in managing the bank's risk that is CAR and NPL. Then this research aim to investigate whether CAR, NPL and Size will give an effect to the profitability of the bank. With the sample of 30 commercial banks that quoted from Indonesian Stock Exchange period 2011-2015 by applying panel data regression analysis, the research result showed that there is a positive and significant effect of CAR toward bank's ROA. NPL had a negative but insignificant effect toward ROA. Firm size had a positive and significant effect toward ROA. It is more profitable to invest in a bigger bank with a high CAR and less NPL. It's implied that it will be more profitable to invest in a bigger bank with a high CAR and less NPL. Even though, it is important to monitor their CAR and NPL level.
\end{abstract}

Keywords: Bank, CAR, NPL, Size, ROA

\section{INTRODUCTION}

A banking that has a primary function as a credit channel for economic agents is a pillar for the economic growth of a country. If credit increased, it will signal the economy of a country is improving. However, the credit disbursement of Indonesian banking is always growing above $10 \%$ before 2014 but after the year 2014 began to decline below $10 \%$. The growth of credit of Indonesian banking is
$10,4 \%$ in 2015 and its declined to $7.87 \%$ in 2016 . Given the decreasing trend in Indonesian Banking credit, it is highly necessary to investigate it cause or determinant. Despite the trend in decreasing in the growth of Indonesian banking credit, the bank should not neglect to manage the risk especially the credit risk in order to maintain its performance. According to Iqbal \& Mirakhor (2011) argued that existence of a strong risk management process can help the private and public banks to minimize exposure to risks and can enhance the competitive ability of the bank in the market [1].

\section{LITERATURE REVIEW}

Every business should have a good performance in order to create a trust from the stakeholders. Otherwise, the stakeholder will not give any attention to the company. So it is crucial to have a performance measurement for a bank [2].

One of the most preferred performance measurement of a bank is Return on Asset (ROA) as suggested in Bank Indonesia regulation PBI no.13/1/PBI/2011 pasal 2. ROA gives a sign of the capital strength of the banking industry, which will depend on the industry; banks that require large initial investment will generally have lower ROA (Appa, 1996; Ahmed et al., 1998; Kolapo et al., 2012) [3].

ROA is a ratio that measures a company's profit after tax or net income against its total assets. The ratio is considered as an indicator of how efficient a company is using its assets to generate earnings before contractual obligation must be paid..In order to get the profit, banks core business is to provide credit or loans to customers. However, providing the credit comes with risk. When banks makes bad loans to customers, the bank will be in serious problems if those loans are not repaid. Therefore, banks should manage the risk especially credit risk [4]. 
Credit management as a apart of risk management is therefore concerned with rewards and risks that have to be objective through cautious and careful risk management, failure of which may possibly bring about legal action, economic loss or harm the banks' name.( Kurawa, 2014). Because of profitability is a function of earnings resulting from decent loans and advances, then follows that banks should effectively manage its credit risks in order to protect and increasing the profitability.( Kurawa, 2014) [5].

Accordingly, Banks should manage the risk Moreover, banks as an important player in an economic of a country will be regulated by the government by imposing a regulation banks' performance in managing the loans. The government agencies formulate and issued the specific rules under law for banking institution to conduct their structure and businesses. (Nasdaq.com, 2016) [6].

Among other restrictions, government regulators required an indicator of Non Performing Loans (NPL) and a minimum capital requirement (as known as $\mathrm{CA}=$ Capital Adequacy Ratio). Capital Adequacy Ratio is an important assessment tool for banking to capture the general safety and soundness of banks. It is generally believe that well-captured bank will be then get a better profitability. In fact the higher the capital the more the profitability of banks [7].

Beside that the profitability of a business depend on its size. Business size is a way to posses the ability of a firm to have and conduct a variety of production capability and multiplicity of services the firm can be offered simultaneously to its customers. In other word, the meaning of the firm size is the size of its management group or the amount of assets it possesses compared to others in the same industry (Sritharan, 2015). Firm size is the speed and extent of growth that is ideal for a specific business. Bank size is usually used to examine the economies or diseconomies of scale in the banking sector. A large bank reduces cost because of economies of scale and scope [8].

\section{RESEARCH METODOLOGY}

The objective of the present study is to ascertain the impact of risk management practices and size on the profitability of commercial banks in Indonesia will be made. To attain this objective, methodology employ the statistical tools and techniques in conducting the research. The research will covered of 30 commercial banks that quoted from Indonesian Stock Exchange period 2011-2015. Those banks should be continually registered in the range period of the research period 2011-2015.

Panel data used from a five year period (2011 to 2015). The panel data were advantageous as they allowed for the study of bank behaviour over a period (Gujarati, 2003). The analysis will be covered into descriptive analysis and regression analysis. For regression analysis, the fixed effects taken into consideration.

The model was proposed in this research which Return On Assets can be predicted from the banks' size and risk management. Risk management will measures of Non Performing Loan and Capital Adequacy Ratio. In a mathematical expression, it may state:

$$
\begin{gathered}
R O A=f(\text { Size }, C A R, N P L) \\
R O A=f(L N T A, C A R, N P L)
\end{gathered}
$$

Whereas,

$\mathrm{ROA}=$ Return on Assets as firm's profitability.

CAR = Capital Adequacy Ratio as firm's capital to risk management.

NPL = Non-performing Loan, Loan level that close to default as risk management.

LNTA $=$ Log Natural of Total Assets, representing firm's size.

\section{THE RESULT AND DISCUSSION}

\section{TABLE I. DESCRIPTIVE STATISTICS}

\begin{tabular}{|c|c|c|c|c|c|}
\hline Variable & Min. & Max. & Range & Mean & $\begin{array}{c}\text { Standard } \\
\text { Deviation }\end{array}$ \\
\hline $\begin{array}{c}\text { LN Total } \\
\text { Assets }\end{array}$ & 15.44 & 30.59 & 15.14 & 19.80 & 3.24 \\
\hline NPL (\%) & 0.14 & 5.88 & 5.74 & 2.14 & 1.32 \\
\hline CAR (\%) & 9.41 & 27.91 & 18.50 & 16.16 & 3.38 \\
\hline ROA (\%) & $(7.64)$ & 22.14 & 29.78 & 2.36 & 4.06 \\
\hline
\end{tabular}

Source: Author's Calculation 2017

Profitability was measured by using Return on Assets. In accordance with our result, on average banking industries had $2.36 \%$ return on assets for 2011 through 2015 . It was distributed as low as $7.64 \%$ to as high as $22.14 \%$. On average, banking industries had $16.16 \%$ Capital Adequacy Ratio to manage the risk of its services. However, in 2011 to 2015 there is a bank that lower its CAR to level $9.41 \%$ or maintain it at level of $27.91 \%$. NonPerforming Loan, which should be avoided were on $2.14 \%$ in average. The lowest level of NPL for 2011 to 2015 was $0.14 \%$ and the highest was $5.88 \%$.

Size of the firm was measured using its total assets. The more the banks' total assets, the bigger its firm size. In this paper we used logarithm natural of total assets to maintain the balance of firm size. We found that there was a huge gap between the smallest bank and the largest bank in term of their total assets. The smallest size was in $15.44 \mathrm{LN}$ total 
assets. The biggest size was 30.59 . The average size of banking LN total assets was 19.80 .

TABLE II. CORRELATION ANALYSIS

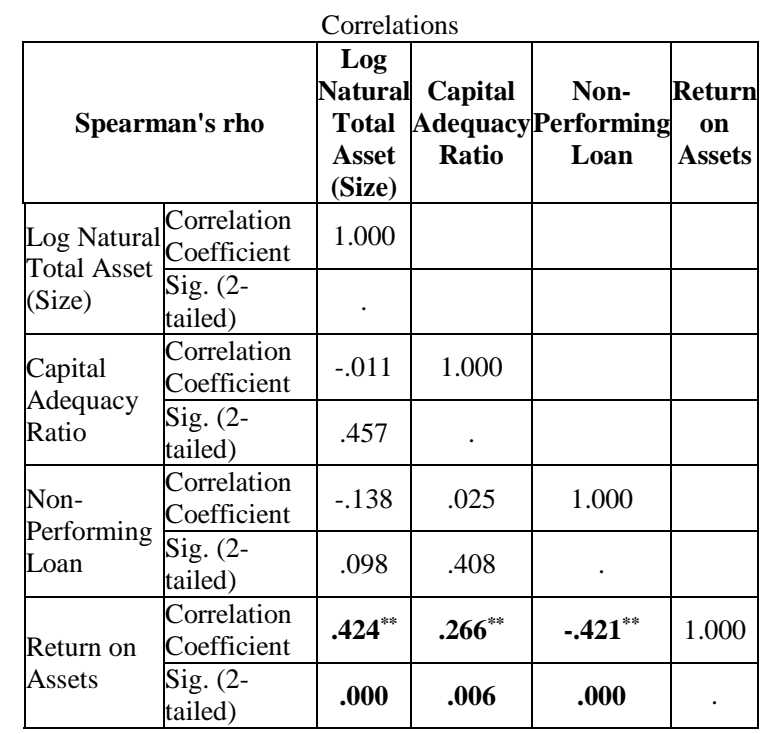

**. Correlation is significant at the 0.01 level (2-tailed).

Source: Author's Calculation 2017

Spearman's rho calculated the correlation between our variables. The table showed significant relationships between the independent variables to our dependents variables, Return on assets. There is a significant relationship between the firm's size, capital adequacy ratio, and their non-performing load to their profitability. As the firm size become bigger, it is more likely to generate a better profitability level. Furthermore, as the firm able to manage higher CAR level, it is more likely to generate more return on assets. If the firm able to suppress their non-performing loan, it will me more likely to generate more return for the firm. Lastly, there is no significant correlation between our independents variables.

\section{TABLE III. REGRESSION FIXED-EFFECT MODEL}

\begin{tabular}{|c|c|c|c|}
\hline $\mathrm{R}$ & $\mathrm{R}$ Square & $\begin{array}{c}\text { Adjusted R } \\
\text { Square }\end{array}$ & $\begin{array}{c}\text { Std. Error of the } \\
\text { Estimate }\end{array}$ \\
\hline .362 & .131 & .101 & 3.53640 \\
\hline \multicolumn{2}{|l|}{$\begin{array}{l}\text { Predictors: (Constant), Log Natural Total Asset (Size), Capital } \\
\text { Adequacy Ratio, Non-Performing Loan }\end{array}$} \\
\hline \multicolumn{2}{|l}{ Dependent Variable: Return on Assets } \\
\hline
\end{tabular}

Source: Author's Calculation 2017

As we evaluate the model, there is a relationship between the predictor toward ROA. However, the proposed model can only explained $13.1 \%$ variabce of ROA. There was $86.9 \%$ variance that can be explained by variables outside the proposed model.
The model was evaluated using fixed-effect regression as we suggest that independency between time-series data from 2011 through 2015. We also treated the explanatory variables as non-random. The regression analysis result were summarized as follow:

TABLE IV. REGRESSION FIXED-EFFECT ANALYSIS

\begin{tabular}{|c|c|c|c|c|c|}
\hline \multirow{2}{*}{ Predictors } & \multicolumn{2}{|c|}{$\begin{array}{c}\text { Unstandardized } \\
\text { Coefficients } \\
\end{array}$} & \multirow{2}{*}{$\begin{array}{c}\text { Standardized } \\
\text { Coefficients } \\
\text { Beta }\end{array}$} & \multirow{2}{*}{$\mathbf{t}$} & \multirow{2}{*}{ Sig. } \\
\hline & B & $\begin{array}{c}\text { Std. } \\
\text { Error }\end{array}$ & & & \\
\hline (Constant) & -7.264 & 3.224 & & $2.253^{-}$ & .027 \\
\hline $\begin{array}{l}\text { Capital } \\
\text { Adequacy } \\
\text { Ratio } \\
\end{array}$ & .307 & .112 & .278 & 2.748 & .007 \\
\hline $\begin{array}{l}\text { Non- } \\
\text { Performing } \\
\text { Loan }\end{array}$ & -.139 & .288 & -.049 & -.481 & .632 \\
\hline $\begin{array}{l}\text { Log Natural } \\
\text { Total Asset } \\
\text { (Size) }\end{array}$ & .262 & .117 & .228 & 2.239 & .008 \\
\hline
\end{tabular}

a. Dependent Variable: Return on Assets

Source: Author's Calculation 2017

Based on the fixed-model regression, we can formulate that,

$$
\begin{aligned}
R O A=-7.264 & +0.307 C A R-0.139 N P L \\
& +0.262 L N T A
\end{aligned}
$$

There is positive and significant effect of CAR toward firm's ROA. As correlation analysis suggest, we found that CAR positively affecting the firm's ROA. One percent increase in CAR will bring out an increase to $0.307 \%$ ROA. Thus, firm should improve their CAR policy by increasing its CAR level.

NPL had a negative but insignificant effect toward ROA. It is true that the presence of NPL may reduce firm's profitability as the load was closed to default. It will be hard for the bank to collect the money if the loan could not be collected. Even though it had an insignificant effect, firm should suppress their NPL level.

Firm size had a positive and significant effect toward ROA. Our finding showed that the bigger the firm, the higher level of ROA can be generated. This research showed that a bigger firm can perform better than the small one. They can generate more income based relatively to the assets used to operate the business. A bigger firm may learned to operate efficiently or cutting cost through their size which can improve its return on assets. 
For investors, it is more profitable to invest in a bigger bank with a high CAR and less NPL. As our findings suggest, it will bring out a better performance for the banks. It is important to monitor their CAR and NPL level.

\section{CONCLUSION AND RECOMMENDATION}

The study slightly confirms that there is a relationship between risk management and profitability in such way that profits of banks are affected by CAR but NPL have an insignificant effect on the profitability. This finding support by Bayyout, (2t015). Moreover, the research finding contrary with $\mathrm{Li}$ and Zou (2014) finding that the NPL have a significant effect on banking profitability and CAR have insignificant effect on the banking profitability. The regression analysis finding concluded that bank in Indonesia had a capital sufficient capacity to generate profitability from their assets. The majority of banks will use credit risk management principles within their institutions for the development of value and evaluating uncertainties in order to prevent the credit default.

\section{ACKNOWLEDGMENT}

The authors gratefully thank and acknowledge that this present research is supported by University of Sumatera Utara. The support is under the research grant TALENTA of Year 2017.

\section{REFERENCES}

[1] Appa, R. (1996). The monetary and financial system (3rd ed.). London: Bonkers Books Ltd.

[2] Ahmad, N. H., \& Ariff, M. (2007). Multi-country study of bank credit risk determinants. International Journal of Banking and Finance, 5(1), 135-152.

[3] Ahmed, A. S., Takeda, C., \& Shawn, T. (1998). Bank loan loss provision: A re-examination of capital management and signalling effects (pp. 1-37). Working Paper, Department of Accounting, Syracuse University

[4] Bayyout, Mohammed, Nermen Sayyad (2015), The Relationship between credit risk management and profitability between investment and Commercial Bank in Palestine, Intemational Journal of Economics and Finance, vol7 n0.11 (2015).

[5] Gujarati, D. (2003). Basic econometrics, McGraw Hill, New York.

[6] Iqbal, Z., \& Mirakhor, A. (2011). An Introduction to Islamic Finance: Theory and Practice. ( $2^{\text {nd }}$ edition John Wiley and Sons (Asia) Pte. Ltd.

[7] Li Fan, Yijun Zou (2014), The Impact of Credit Risk Management on Profitability of Commercials Banks : A Study of Europe, Master Degree, UMEA University.

[8] Kolapo, T. F., Ayeni, R. K., \& Oke, M. O. (2012). Credit risk and commercial banks' performance in Nigeria: A panel model approach. Australian Journal of Business and Management Research, 2 (2), 31-38.

[9] Kurawa Junaidu Muhammad and Sunusi Garba (2014): An Evaluation of the Effect of Credit Risk Management (CRM) on the Profitability of Nigerian Banks Joumal of Modern Accounting and Auditing, ISSN 1548-6583 January 2014, Vol. 10, No. 1, 104-115.

[10] Sritharan, V., (2015). Does firm size influence on firm ${ }^{\text {ee }} \mathrm{s}$ Profitability? Evidence from listed firms of Sri Lankan Hotels and Travels sector. Research Journal of Finance and Accounting. ISSN 2222-2847. 